\title{
CONSERVATION OF BAMBOO SPECIES IN A MINI URBAN ECOSYSTEM OF BANGLADESH
}

\author{
Rahman, M. M., W. Parvin, N. Sultana and S. A. M. Tarek \\ Silviculture Genetics Division, Bangladesh Forest Research Institute, Chittagong 4000, Bangladesh
}

\begin{abstract}
A bambusetum conserving all bamboo species of Bangladesh was established at Bangladesh Forest Research Institute campus, Chittagong. The Silviculture Genetics Division conducted the research study. The purpose of the study was to collect, centralize and conserved all bamboo species of Bangladesh in a setum. The planted propagules of various species include offsets, part-clump, branch cutting, seed and seedling and tissue culture plantlets. So far 33 species of bamboos have been collected from different parts of the country as well as introduced from China and Thailand. The total land area of the bambusetum is approximately 2.0 hectares. It is the only bamboo germplasm centre of the country, which includes all bamboo species. It serves as a bamboo information center for the scientists, academicians, students and visitors as well.
\end{abstract}

Key words: Bamboo, conservation, urban, ecosystem

\section{INTRODUCTION}

Bamboo is very essential and useful bioresource in tropics and sub-tropics. It has got various importances also in the other parts (Temperate region) of the world. Bamboo is a special type of long, but strong hard and durable plant resource variously used in every sphere of life.

Bamboos are mainly distributed in tropical, sub-tropical zones on the earth, and tropical monsoon region. There are more than 1,500 species in 75 genera of bamboos in the world. The total area of bamboo forest in the world amounts to 14 million hectares distributed mainly in bamboo zones of Asia, Pacific, Americas and Africa. However, East Asia and Southeast Asia have the largest bamboo forest areas including some $80 \%$ of the species of the world.

China is the world leading country both in terms of bamboo species and the growing area. It ranks first in the world. There are more than 500 species of bamboos belonging to 40 genera in China, nearly half of the globe's total. The number of species and genera are more than in any other country or region in the world.

However, Bangladesh lies in the north-east part of south Asia roughly between $20^{\circ} 75^{\prime} \mathrm{N}$ and $25^{\circ} 75^{\prime} \mathrm{N}$. The country enjoys generally tropical monsoon climate. Bangladesh is basically a plain land country. Except the hilly regions in the north-east and south-east, some areas of highlands in the north and western parts of the country consist of low, flat and fertile land. As a result, the soil and climatic conditions are favorable for the growth and development of bamboos.

There are about 9 genera and 33 species of bamboos growing throughout the country. It has 5 lac (half a million) hectares bamboo plantations both in village and forest lands. Seven bamboo species are grown in the forest land covering 2 lac hectares and others 26 species are found as the cultivated bamboos in the village land covering 3 lac hectares. The major forest bamboo producing areas of Bangladesh are the forests of Sylhet, Chittagong and Cox's Bazar. The Kassalong, Rankhiang, Sangoo and Matamuhuri researves are the main bamboo producing areas in the geographic regions of the Chittagong Hill Tracts. In the northern part, Patharia and Rajkandi reserves of Sylhet forest are also rich with natural bamboo areas (Banik 2000).

Bangladesh has a variety of bamboo resources, which are vital to continuing development of the country's economy, especially at the rural sector. It has also been used in more than $65 \%$ farms as 
agricultural implements. Green leaves of bamboo are also used as fodder (50\%) during the long period of flood (Chowdhury 1993).

Bangladesh presently suffers a deficit in bamboo supply. Forecasts are that the shortfall will increase alarmingly day by day due to a large-scale death of forest bamboo and gregarious flowering. The available forest supply is about $20 \%$ and the remaining $80 \%$ is coming from the village source. So, the bulk of the bamboo is being produced by farmers not foresters. The current accelerated rate of deforestation alarmingly erodes the genetic resources of trees and bamboos. Therefore, there is an urgent need to conserve genetic resources of bamboos both in their natural habitat (in situ) and in ex situ conservation plots. The in situ bamboo vegetation is often threatened due to uncontrolled biotic interference. Therefore, it was necessary to centralize and conserve the different bamboo species in protected areas. Bangladesh Forest Research Institute (BFRI) is the pioneer institute for bamboo research in the country, as well as the region. This institute initiated bamboo research on different aspects, namely biology, silviculture, management and utilization in early 1970s (Alam 2001). The efforts to collect and centralize the species and their variants were started since 1972-73 inside the campus of BFRI, Chittagong (Banik 2000). The total land of the bambusetum is approximately 2.0 hectares under the influence of tropical monsoon climate having a range of annual air temperature 10$35^{\circ} \mathrm{C}$, soil temperature $22-29^{\circ} \mathrm{C}$ at $50-200 \mathrm{~cm}$ depth, and total annual rainfall $2500-3000 \mathrm{~mm}$. Rainfall is high during the end of May to August and dry months are mostly from November to March. All the species have been planted serially in lines. An individual conservation plot was established in 2006 with eleven bamboo species at the setum. The planted propagules of various species include offsets, partclump, branch cutting, seed and seedling and tissue culture plantlets. Each species been planted in one or more lines collected from different sources.

\section{Sources of bamboo materials}

\section{MATERIAL AND METHODS}

The offsets, seeds, branch cutting, part of culm and tissue culture plantlets were used for conservation of bamboo species. Offsets and seeds were collected from different parts of the country and also introduced from Thailand and China. The tissue culture plantlets were developed in the tissue culture laboratory of Silviculture Genetics Division of BFRI.

\section{Propagation methods for planting material development \\ Offset collection and development}

Bamboos are conventionally propagated by offsets. An offset propagule is composed of basal parts of a culm along with an underground rhizome portion. The desired length of the culm part of an offset is 1.0-1.5 m with 3-4 nodes bearing viable branch buds. The offset always should be young (1- 2 years old) and collected from a healthy clump of a desired species. Offsets are normally obtained and transplanted just before the rainy season or after a pre-monsoon shower, i.e. from mid-March to April. If collected later, when culms are emerging, the buds on the rhizome will be elongated and liable to damage and as a result the offset will fail to survive in the field. Offset method is suitable for thick wall bamboo. Success of offset planting in thin-walled bamboo species is relatively poor and varies greatly from species to species. (Banik 1987b, 1995a).

\section{Pre-rooted and pre-rhizomed branch cutting}

Most of the thick-walled cultivated bamboo species in Bangladesh have branches having spontaneous in situ rooting and rhizome at the swollen base (Banik 1980, 1987b). Aerial roots and rhizomes of such cuttings are not always active. Therefore, these cuttings have to be collected from the 
nodes of the standing culms from April to June and be placed in the sand media of propagation beds. A propagation bed is a 3-layered sand bed, each of the layers is $7-10 \mathrm{~cm}$ deep. The bed remains well drained. A propagation bed is $1.2 \mathrm{~m}$ wide and $12 \mathrm{~m}$ long in size, situated on level ground in the nursery. The collected branch cuttings from the culms are placed on the sand media under mist for one month. Within 30 days, the branch cuttings produce profuse active roots.

\section{Culm cutting}

Culm cuttings are the culm segments with 1-3 nodes with buds or branches. The culms selected for the cuttings should not be more than 2 years old and buds should be healthy. The cuttings are placed in the sand bed for rooting. About 30-70 \% success can be obtained depending on the species. In some species like Dendrocalamus longispathus success can be enhanced in both branch cuttings and culm cutting treatment by treating them with IBA or NAA $(100-150 \mathrm{ppm})$. Once rooted, the cuttings are transferred to polythene bags and kept in the nursery, with regular weeding and watering. Like seedlings, cuttings are kept in the nursery at least up to the next monsoon. Survival of these types of cuttings in the field is high, almost 85-90\%. The culms can be harvested after 3-5 years in plantation.

\section{Using seeds}

Bamboo species exhibit exceptional flowering behavior. The possible next flowering year of the major bamboo species of the country is forecasted on the basis of their estimated inter seeding period. The most common bamboo species cultivated in the villages, usually flower grows very sporadically or in isolated clumps after many years. But they do not produce any seeds. Estimates were made on analyzing the past flowering records of each of the major bamboo species in the country. Estimated ranges of flowering cycles of different bamboo species were found to be within 20-80 years, but majority within 30-50 years cycle (Banik 1980, Hasan 1973).

Seed collection is a vital component since bamboo flowers irregularly. Generally, seeds produced from mid-February to May are healthy and more viable. Bamboo seeds germinate well under shade than in open sunlight. Seeds should be sown in the polythene bags just after collection. The germination medium (soil and cowdung 3:1) should be wet but not waterlogged. Seeds start germinating within 3-7 days of sowing and continue up to 15-25 days. Bamboo seeds are short lived, losing their viability within one to two months (Banik 1987a).

\section{Tissue culture}

Tissue culture research on bamboo was started at Silviculture Genetics Division of BFRI, Chittagong since 1990. Studies were made on 14 bamboo species Bambusa bambos, B. glaucescens, B. nutans, B. cacharensis, B. salarkhanii, B. vulgaris-var-striata, B. vulgaris, B. balcooa, Dendrocalamus giganteus, D. brandisii, D. longispathus, Melocanna baccifera, Thyrsostachys oliveri and Thyrsostachys siamensis.

Bioresource conservation stands essential as it is renewable resource in characters. Conservation works were conducted at the Silviculture Genetics Division of BFRI and started in 1972-73. An attempt was made in the present investigation to conserve the bioresource. The results obtained in the experiment stand applicable and as per procedure followed in the methodology.

\section{RESULTS AND DISCUSSION}

Total 33 bamboo species of nine genera were conserved in the mini urban arboretum of BFRI campus in Chittagong (Fig. 1). The genera are Bambusa, Dendrocalamus, Dinochloa, Gigantochloa, Melocalamus, Melocanna, Oxytenanthera, Schizostachyum (Neohouzeaua), and Thyrsostachys. Most of the species belong to the genera Bambusa and Dendrocalamus, while the remaining genera have only 
one to two species each. Seven species of bamboos grow naturally in the forests of Bangladesh. Among them muli bans (Melocanna baccifera) is most common. Other species - mirtinga (Bambusa tulda), orah (Dendrocalamus longispathus), dalu (Neohouzeaua dullooa Syn. Schizostachyum dullooa) and kali (Oxytenanthera nigrociliata) occur sporadically either in association with muli or in isolation forming small patches of pure stands. The other two species lata (Melocalamus compactiflorus) and pecha (Dendrocalamus hamiltonii) are localized only in some limited areas of Cox's Bazar and Sylhet forests, respectively. The forest bamboo species are thin-walled and not so tall like village grown species. Melocanna baccifera, a major forest bamboo, is somewhat different under natural conditions and the boundary of an adult clump cannot be distinguished, and isolated culms emerge at long distance (1-1.5 $\mathrm{m})$ from each other from the spreading rhizome system.

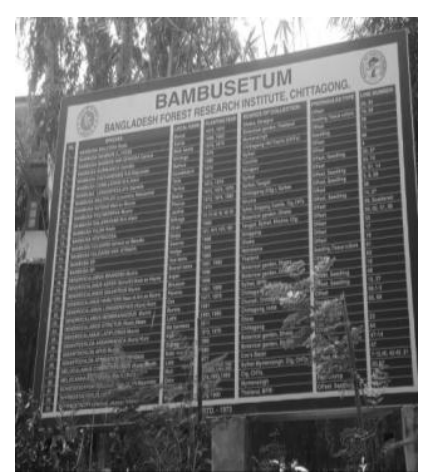

a.

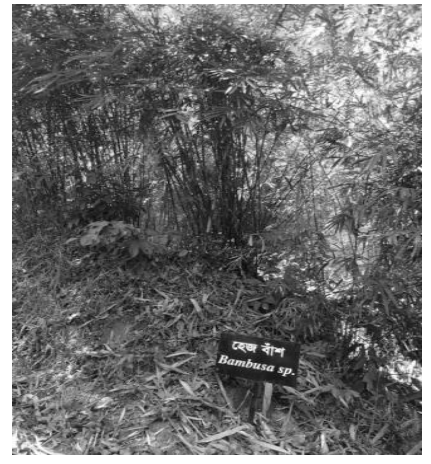

e.

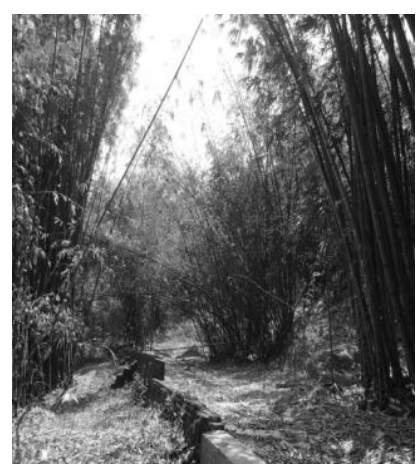

b.

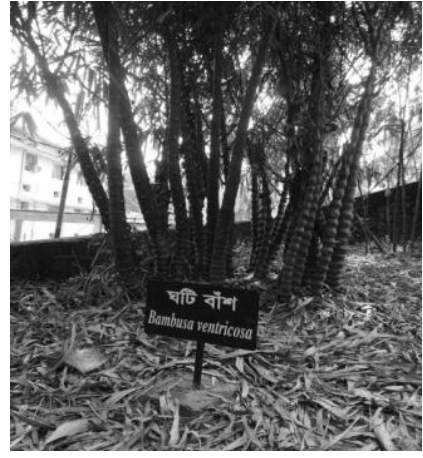

f.

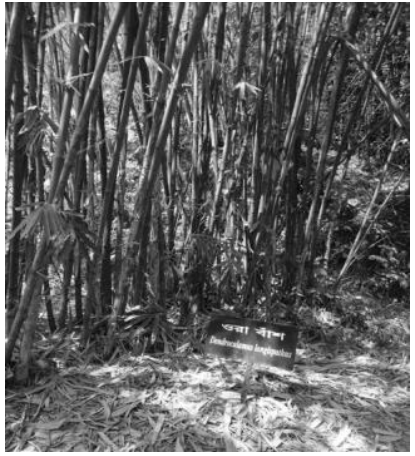

c.

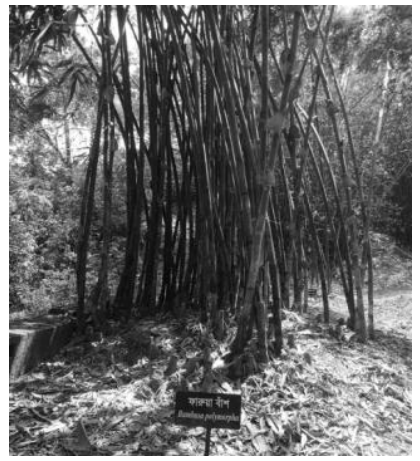

g.

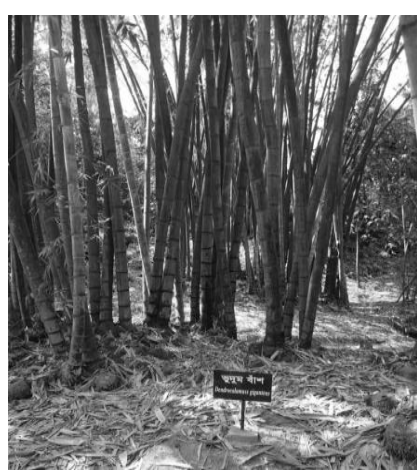

d.

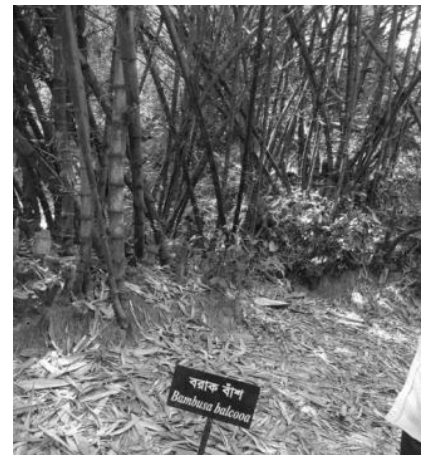

h.

Fig. 1. Different bamboo species conserve at BFRI Bambusetum, Chittagong: a. list of bamboos, b. trail inside bambusetum, c. Dendrocalamus longispathus (Ora bansh), d. D. giganteus (Bhudum bansh), e. Bambusa sp. (Hedge bansh), f. B. ventricosa (Ghati bansh), g. B. polymorpha (Farua bansh) and h. B. balcooa (Borak bansh).

The remaining 26 species are cultivated bamboo grown in the homestead. These species are clumpforming, usually congested in nature with large, tall, branchy culms and thick walled. Thirty three bamboo species have been collected from different parts of the country as well as from China and Thailand. Bambusa bambos was collected from different parts of Bangladesh and one seed source from Kanchanburi, Thailand. The monopodial species Phyllostachys pubescens and the Dendrocalamus latiflorus (edible young shoot) were collected from People's Republic of China. All the species have been planted serially in lines. A conservation plot was established with tissue culture plantlets of 11 bamboo species at the bambusetum (viz. Bambusa bambos, B. nutans, B. cacharensis, B. salarkhanii B. vulgaris var. striata, B. vulgaris, B. balcooa, Dendrocalamus giganteus, D. brandisii, Thyrsostachys oliveri and Thyrsostachys siamensis). Tissue culture protocols were of 14 important bamboo species from branch nodal bud culture. MS and B5 media were found suitable for bamboo tissue culture. Both 
solid and liquid media were used supplemented with BAP, Kn, 2ip as cytokinins and IBA, NAA as auxins. Direct proliferation as well as callus formation resulted in this experiment. Tissue culture plantlets of 14 bamboo species (viz. Bambusa bambos, B. glaucescens, B. nutans, B. cacharensis, B. salarkhanii B. vulgaris-var-striata, B. vulgaris, B. balcooa, Dendrocalamus giganteus D. brandisii, $D$. longispathus, Melocanna baccifera, Thyrsostachys oliveri and Thyrsostachys siamensis) were produced from branch nodal bud culture in MS (Murasige and Skoog 1962) medium supplemented with different cytokinin (BAP, KIN) and auxins (IBA and NAA) at different concentrations (Islam and Rahman 2005).

The planted propagules of various species include offsets, part-clump, branch cutting, seed, seedling and tissue culture plantlets. Each species was planted in one or more lines collected from different sources (Table 1).

Table 1. List of bamboo species conserved in the Bambusetum of BFRI campus, Chittagong.

\begin{tabular}{|c|c|c|c|c|}
\hline Local name & Scientific name & Plantation year & Source of collection & Propagule type \\
\hline Borak & Bambusa balcooa & 1973,1975 & Dinajpur, Dhaka & Offset, Tissue Culture \\
\hline Kanta & B. bambos & $1990,1991,1992$ & Thailand, Keochia, Chittagong & Tissue Culture, Seedlings \\
\hline Bish Kanta & B. bambos var.spinosa & $1974,75,80$ & Mymensingh & Offset, Seedlings \\
\hline Mirtinga & B. tulda & $\begin{array}{l}1973,74,78,79,80,81 \\
86,89,90,91\end{array}$ & $\begin{array}{l}\text { Sylhet, Chittagong, Chittagong Hill } \\
\text { Tract, Serjganj, Brammonbaria }\end{array}$ & Seedlings, Offset \\
\hline Bethua & B. cacharensis & 1989 & Sylhet & Seedlings \\
\hline Kanakaich & B. comillensis & 1979 & comilla & Offset \\
\hline Tetua & B. jaintiana & 1973,74 & Srimonagal, Sylhet & Offset \\
\hline Choi & B. multiplex & 1973,74 & Chittagong & Offset \\
\hline Makla & B. nutans & $1973,74,75,80$ & Sylhet, Tangail & Seedlings, Offset, Tissue Culture \\
\hline Farua & B. polymorpha & $1972,73,74,82,89,90$ & Chittagong Hill Tract, Sylhet & Offset, Branch cutting \\
\hline Korjoba & B. salarkhanii & 1973,74 & Mymensingh & Offset \\
\hline Mitinga & B. burmanica & 1972 & Chittagong & Offset \\
\hline Baijja & B. vulgaris & $1973,74,75,81$ & $\begin{array}{l}\text { Tagail, Sylhet, Khulna, } \\
\text { Chittagong }\end{array}$ & $\begin{array}{l}\text { Offset, Branch cutting, } \\
\text { Tissue Culture }\end{array}$ \\
\hline Sharna & B. vulgaris var. striata & 1986 & Serajgonj & $\begin{array}{l}\text { Offset, Branch cutting, } \\
\text { Tissue Culture }\end{array}$ \\
\hline Ghati & B. ventricosa & 1993 & Botanical Garden, Dhaka & Branch cutting, Offset \\
\hline Hedge & Bambusa sp. & 1989 & Dhaka & Offset \\
\hline Brandisi & Dendrocalamus brandisii & 1992,93 & Kanchanburi, Thailand & Tissue Culture, Seedlings \\
\hline Bhudum & D. giganteus & $1980,82,84,93$ & Botanical Garden, Dhaka & $\begin{array}{l}\text { Tissue Culture, Branch } \\
\text { cutting, Offset }\end{array}$ \\
\hline Pecha & D. hamiltonii & 1979,81 & Sylhet & Offset \\
\hline Ora & D. longispathus & $1972,74,75,79,80$ & Chittagong & Seedlings \\
\hline Membra & D. membraceus & 1991 & Chittagong & Offset \\
\hline Lathi & D. strictus & $1991,93,95$ & Chittagong & Offset, Seedlings \\
\hline Kali & Gigantochloa andarmanica & 1973,79 & Chittagong & Offset, Seedlings \\
\hline Zizag & G. apus & 1993 & Botanical Garden, Dhaka & Offset \\
\hline Kala & G. atroviolacea & 1993 & Botanical Garden, Dhaka & Offset \\
\hline Lata & Melocalamus compactiflorus & 1977 & Cox’s Bazar & Seedlings \\
\hline Muli & Melocanna baccifera & $\begin{array}{l}1972,74,75,89,91 \\
92,93,95\end{array}$ & $\begin{array}{l}\text { Sylhet, Mymensingh, Chittagong, } \\
\text { Chittagong Hill Tract }\end{array}$ & $\begin{array}{l}\text { Offset, Seedlings, Tissue } \\
\text { Culture }\end{array}$ \\
\hline Dalu & Schizostachyum dullooa & $1974,92,90,2001$ & Chittagong, Sylhet & Part clump, Offset, Seedlings \\
\hline Thai & Thyrsostachys siamensis & $1979,90,92$ & Thailand & Offset, Seedlings \\
\hline Rangoon & T. oliveri & 1990 & Mymensingh & Part clump \\
\hline Talla & B. longispiculata & $1973,74,75,79,80$ & Dinajpur & Offset \\
\hline Chaina & D.latiflorus & 2010 & China & Offset \\
\hline Wappi & Thyrsostachys sp. & 2016 & Chittagong Hill Tract & Offset \\
\hline
\end{tabular}


In south Asia, some bamboo species especially the village bamboo species like $B$. balcooa, $B$. vulgaris, D. giganteus, D. stratus etc. possess very wide diameter culms with thick walls, while some others like B. glaucescens, B. cacharensis, M. baccifera, S. dullooa etc. have small diameter culms and thin walls. However, culm diameter may increase or decrease depending on the site conditions and the age of the plant. The diameter of the successively emerged culms increases with the age of the clumps. Thus bamboos can be grouped into thin and thick walled species. The culm diameter and wall thickness ratio of 10 bamboo species of Bangladesh have been recorded at BFRI's bambusetum. Among those $D$. giganteus, D. strictus and B. balcooa have maximum $(3.45,3.34$ and $2.82 \mathrm{~cm}$, respectively) wall thickness in the basal portion of the culms, while $S$. dullooa and $G$. andarmanica possess culms with thinnest wall $(0.68$ and $0.96 \mathrm{~cm}$, respectively) (Table 2). However, when ratio between wall thickness (Wt) and culm diameter (Dia) is considered in the basal portion of the culm, the grouping of thick and thin walled bamboos becomes different. The ratio values of $S$. dullooa and $G$. andarmanica were higher than thick wall species like B. vulgaris and D. giganteus (Table 2). Thus, it appears that the ratio between wall thickness and culm diameter might be an important consideration in classifying bamboo as thick and thin wall species. It was observed that the value of ratio is found to be always lowest (0.060.13) in the mid zones than those of base and top culm portions in all bamboo species (Table 2). This indicates that in relation to the diameter and mid culm zones have thinnest wall thickness than those of basal and top portion of the culms (Banik 2000).

A systematic investigation on the variability of growth and performance of different bamboo species of Bangladesh was initiated at BFRI. In some areas farmers or members of local community have conserved specific bamboo species and of different germplasm unrecorded in the past. In some areas exotic species are included. The plants are well conserved and maintained. Majority of the farmers in the areas of Sylhet-Comilla, bordering Indian state of Tripura, have cultivated and conserved Thyrsostachys oliveri in their homesteads. No seed bank of bamboo species is available in the country. However, it could be initiated to establish a bamboo seed bank at BFRI near future.

Table 2. Ratio of wall thickness (Wt) / Diameter (Dia) measurement at three different culm position in 10 bamboo species of Bangladesh.

\begin{tabular}{lccccccccc}
\hline Species & \multicolumn{3}{c}{ Base } & \multicolumn{3}{c}{ Mid } & \multicolumn{3}{c}{ Top } \\
\cline { 2 - 10 } & Dia $(\mathbf{c m})$ & Wt $(\mathbf{c m})$ & Ratio & Dia $(\mathbf{c m})$ & Wt $(\mathbf{c m})$ & Ratio & Dia $(\mathbf{c m})$ & Wt $(\mathbf{c m})$ & Ratio \\
\hline Dendrocalamus giganteus & 18.72 & 3.45 & 0.187 & 11.0 & 0.70 & 0.063 & 0.42 & 0.10 & 0.238 \\
D. longispathus & 5.30 & 1.79 & 0.337 & 4.10 & 0.36 & 0.088 & 0.88 & 0.19 & 0.215 \\
D. strictus & 6.52 & 3.34 & 0.512 & 5.00 & 0.54 & 0.130 & 0.63 & 0.22 & 0.350 \\
Bambusa balcooa & 9.15 & 2.82 & 0.308 & 7.82 & 0.92 & 0.117 & 1.24 & 0.36 & 0.290 \\
B. vulgaris & 8.32 & 1.72 & 0.206 & 7.65 & 0.62 & 0.082 & 0.70 & 0.22 & 0.163 \\
B. polymorpha & 9.25 & 1.19 & 0.128 & 7.78 & 0.74 & 0.095 & 1.35 & 0.22 & 0.163 \\
B. tulda & 5.75 & 1.17 & 0.203 & 4.52 & 0.41 & 0.091 & 1.02 & 0.21 & 0.205 \\
M. baccifera & 4.05 & 2.28 & 0.316 & 3.25 & 0.29 & 0.089 & 0.60 & 0.16 & 0.267 \\
G. andarmanica & 4.01 & 0.96 & 0.239 & 3.04 & 0.31 & 0.101 & 0.69 & 0.10 & 0.145 \\
S. dullooa & 2.87 & 0.68 & 0.237 & 2.65 & 0.24 & 0.090 & 0.86 & 0.12 & 0.139 \\
\hline
\end{tabular}

Conservation is a process of wise use and careful management of resources as to obtain the maximum possible benefits from them for present and future generation. Methods of the process include preservation, balanced multiple use, reducing unnecessary waste recycling, reuse and decrease resources use. To materialize the steps of the process one should be a conservationist (Bashar and Khan 2015). A conservationist is to press his concerns for the present and future survival of human beings and other species by not wasting and not irreversibly depleting or degrading the biological, physical, and chemical wealth of the world on which all life depends. The pressing must be exercised without doing any hamper 
to the nature. The present attempt has been made on the subject by selecting bamboo as the example of biological resources. The experiments are being continued at the tissue level and sub-cellur level with recording data on the ecosystem level also. This attempt could be an example to do further researche on the field in Bangladesh.

\section{ACKNOWLEDGEMENTS}

Authors are thankful to the Ministry of Environment and Forest, as well as the Director of Bangladesh Forest Research Institute, Chittagong for the financial support to carry out this study.

\section{REFERENCES}

Alam, M. K. 2001. Bamboos of Bangladesh: A field identification manual. Bangladesh Forest Research Institute, Chittagong, Bangladesh, pp. 1- 35.

Banik, R. L 2000. Silviculture and field-guide to priority bamboos of Bangladesh and South Asia. Government of the people's republic of Bangladesh, Bangladesh Forest Research Institute, Chittagong. $186 \mathrm{pp}$.

Banik, R. L. 1980. Propagation of bamboos by clonal methods and by seeds. In: G. Lesserd and A. Chouinard (eds.). Bamboo Research in Asia. IDRC, Ottawa, Canada, pp. 139-150.

Banik, R. L. 1987a. Seed germination of some bamboo species. Indian Forester. 113(8): 578-586.

Banik, R. L. 1987b. Techniques of bamboo propagation with special reference to pre-rooted and prerhizomed branch cuttings and tissue culture. In: A. N. Rao, G. Dhanaranjan and C. B. Sastry (eds.). Recent Res. on Bamboos. CAF, Beijing and IDRC, Singapore, pp. 160-169.

Banik, R. L. 1995a. A Manual for Vegetative Propagation of Bamboos. INBAR Technical Report No. 6. IDRC, Canada/FAO-FORTIP/BFRI. 66 pp.

Bashar, M. A. and H. R. Khan. 2015. Vision on Bioresource recognition and bioresource management: Bangladesh perspectives. J. biodiverse. conserve. bioresour. manag. 3(1): 1-14.

Chowdhury, M. K. 1993. Agroforestry in homestead and cropslands: existing practices and potentials. In: Tej. B. S. Mahat (ed.). Agroforestry training course modules for Bangladesh. BARC-Winrock International, Dhaka, Bangladesh, pp. 35-48.

Hasan, S. M. 1973. Seeding behaviour of Bangladesh bamboos. Bano Biggyan Patrika. 5(2): 21-36.

Islam, S. A. M. N. and M. M. Rahman. 2005. Micro-cloning in Commercially Important Six Bamboo Species for Mass Propagation and at a Large Scale Cultivation. P.T.C and Biotech. 15(2): 103-111.

Murashige, T. and F. Skoog. 1962. A revised medium for rapid growth and bioassays with tobacco tissue cultures. Physiol. Plantarum. 15: 473-497. 
J. biodivers. conserv. bioresour. manag. 3(2), 2017 